\title{
Spatiotemporal spread of sarcoptic mange in the red fox (Vulpes vulpes) in Switzerland over more than 60 years: lessons learnt from comparative analysis of multiple surveillance tools
}

Simone Roberto Rolando Pisano ${ }^{1} \mathbb{0}$, Fridolin Zimmermann² ${ }^{0}$, Luca Rossi ${ }^{3}$, Simon Capt ${ }^{4}$, Ezgi Akdesir ${ }^{5}$, Roland Bürki ${ }^{2}$, Florin Kunz ${ }^{2}$, Francesco Carlo Origgi ${ }^{1}$ and Marie-Pierre Ryser-Degiorgis ${ }^{1 *}$ (i)

\begin{abstract}
Background: Sarcoptic mange is a contagious skin disease of wild and domestic mammals caused by the mite Sarcoptes scabiei. Reports of sarcoptic mange in wildlife increased worldwide in the second half of the 20th century, especially since the 1990s. The aim of this study was to provide new insights into the epidemiology of mange by (i) documenting the emergence of sarcoptic mange in the red fox (Vulpes vulpes) in the last decades in Switzerland; and (ii) describing its spatiotemporal spread combining data obtained through different surveillance methods.

Methods: Retrospective analysis of archived material together with prospective data collection delivered a large dataset from the 19th century to 2018. Methods included: (i) a review of historical literature; (ii) screening of necropsy reports from general health surveillance (1958-2018); (iii) screening of data on mange (1968-1992) collected during the sylvatic rabies eradication campaign; (iv) a questionnaire survey $(<1980-2017)$ and (v) evaluation of camera-trap bycatch data (2005-2018).

Results: Sarcoptic mange in red foxes was reported as early as 1835 in Switzerland. The first case diagnosed in the framework of the general health surveillance was in 1959. Prior to 1980, sarcoptic mange occurred in non-adjacent surveillance districts scattered all over the country. During the period of the rabies epidemic (1970s-early 1990s), the percentage of foxes tested for rabies with sarcoptic mange significantly decreased in subregions with rabies, whereas it remained high in the few rabies-free subregions. Sarcoptic mange re-emerged in the mid-1990s and continuously spread during the 2000-2010s, to finally extend to the whole country in 2017. The yearly prevalence of mange in foxes estimated by camera-trapping ranged from $0.1-12 \%$.
\end{abstract}

Conclusions: Sarcoptic mange has likely been endemic in Switzerland as well as in other European countries at least since the mid-19th century. The rabies epidemics seem to have influenced the pattern of spread of mange in several locations, revealing an interesting example of disease interaction in free-ranging wildlife populations. The combination of multiple surveillance tools to study the long-term dynamics of sarcoptic mange in red foxes in Switzerland proved to be a successful strategy, which underlined the usefulness of questionnaire surveys.

\footnotetext{
*Correspondence: marie-pierre.ryser@vetsuisse.unibe.ch

${ }^{1}$ Centre for Fish and Wildlife Health (FIWI), Department of Infectious Diseases and Pathobiology, Vetsuisse Faculty, University of Bern, Laenggassstrasse 122, PO Box, 3001 Bern, Switzerland

Full list of author information is available at the end of the article
} (http://creativecommons.org/licenses/by/4.0/), which permits unrestricted use, distribution, and reproduction in any medium, provided you give appropriate credit to the original author(s) and the source, provide a link to the Creative Commons license, and indicate if changes were made. The Creative Commons Public Domain Dedication waiver (http://creativecommons.org/ publicdomain/zero/1.0/) applies to the data made available in this article, unless otherwise stated. 
Keywords: Sarcoptes scabiei, Scabies, Rabies, Camera-trapping, Questionnaire, Necropsy, Post-mortem examination, Surveillance, Disease interference

\section{Background}

The burrowing mite Sarcoptes scabiei (Acarina: Sarcoptidae) is the aetiological agent of sarcoptic mange, a highly contagious skin disease affecting more than a hundred of domestic and wild mammal species worldwide $[1,2]$. Susceptibility to sarcoptic mange and the resulting clinical picture, pathological features and mortality vary substantially between species [1, 3, 4]. Among native and invasive European wild carnivores, sarcoptic mange has been reported in canids, felids, mustelids and procyonids [5-9].

In free-ranging populations sarcoptic mange can have either an epidemic or an endemic nature, with an initial epidemic occurrence gradually transitioning to an endemic one [10]. Epidemics of sarcoptic mange rapidly spread throughout naïve populations over broad geographical areas and are associated with dramatic drops in host density and substantial structural shifts in population dynamics [7, 11-15]. Impressive epidemics of sarcoptic mange in red foxes (Vulpes vulpes; from here simply referred to as "fox(es)") and other wild carnivores occurred in Fennoscandia and Denmark in the 1960s-1990s [7, 14, 16], where regional fox mortality reached $90 \%[7,17]$. Several outbreaks in foxes were also reported in Great Britain in the 1990s [13].

Endemic situations are characterized by a cyclic pattern. Outbreaks are typically limited in time and space and followed by apparently long disease absences and a parallel emergence in adjacent regions [18, 19]. Mortality is generally low, implying only short-term local population decreases $[1,18,20]$. Endemic situations in fox populations have been described in several European countries, such as Denmark [21], Germany [20], Poland [22], Spain [18] and Great Britain [13, 23].

Although known since biblical times in both humans (disease referred to as scabies) and livestock [24, 25], long-term documentation of sarcoptic mange in wildlife populations is rare [1] and often found in non-English literature only. Early scientific descriptions of sarcoptic mange in wildlife date back to the end of the 19th century and the first half of the 20th century [26-30] and $S$. scabiei in foxes has been documented since the beginning of the 19th century [31]. Nevertheless, reports of sarcoptic mange in wild mammalian species, including foxes and other sympatric carnivores in Europe have increased since the second half of the 20th century, becoming exponential since the 1990s [7, 13, 15, 32-37]. This increase was interpreted as an emerging disease new to some parts of Great Britain [38, 39] and Germany [40]. The reasons for this trend are still unknown and may be attributable to changes in the interactions among mites, hosts and their environment, as well as to the increase of wildlife disease surveillance and research.

In Switzerland, epidemics of sarcoptic mange in foxes were reported in the Northwestern Alps and around the city of Geneva between 1996 and 1998 [11, 41]. The disease was also detected in mustelids [6] and in the reintroduced Eurasian lynx (Lynx lynx) population for the first time in 1999 [5]. Since then, sarcoptic mange has also been reported in wild boar (Sus scrofa), although in this species it is likely caused by different $S$. scabiei strain(s) [42]. These findings raised the question as whether mange was an emerging disease new to Switzerland, whether it would further spread and which impact it would have on autochthonous free-ranging wildlife.

The aim of this study was to provide new insights into the epidemiology of sarcoptic mange by (i) documenting the emergence of sarcoptic mange in the red fox in the last decades in Switzerland; and (ii) describing its spatiotemporal spread by combining data obtained with different surveillance methods.

\section{Methods}

Study area

Switzerland $\left(41,285 \mathrm{~km}^{2}\right)$ is an Alpine country in central Europe. It is divided into 26 political subunits (cantons) further subdivided in districts of surveillance of different sizes belonging to three main biogeographical regions (Alps, Plateau and Jura, covering around 63\%, 27\% and $10 \%$ of the country surface area (CSA), respectively) and 11 subregions (with the respective cardinal and intercardinal points spelled with capital letters, Fig. 1).

\section{Case definition}

For this study, mange-like lesions (MLL) were defined as mild to severe encrustations on the skin with or without alopecia, skin thickening and hyperpigmentation, characterized by a typical body distribution and progression of the lesions [4]. Sarcoptic mange was defined as the presence of MLL associated with the detection of intradermal mites consistent with S. scabiei. MLL (with or without mite detection) are typical signs of subacute to chronic stages of S. scabiei infection and can therefore be used for disease detection. 


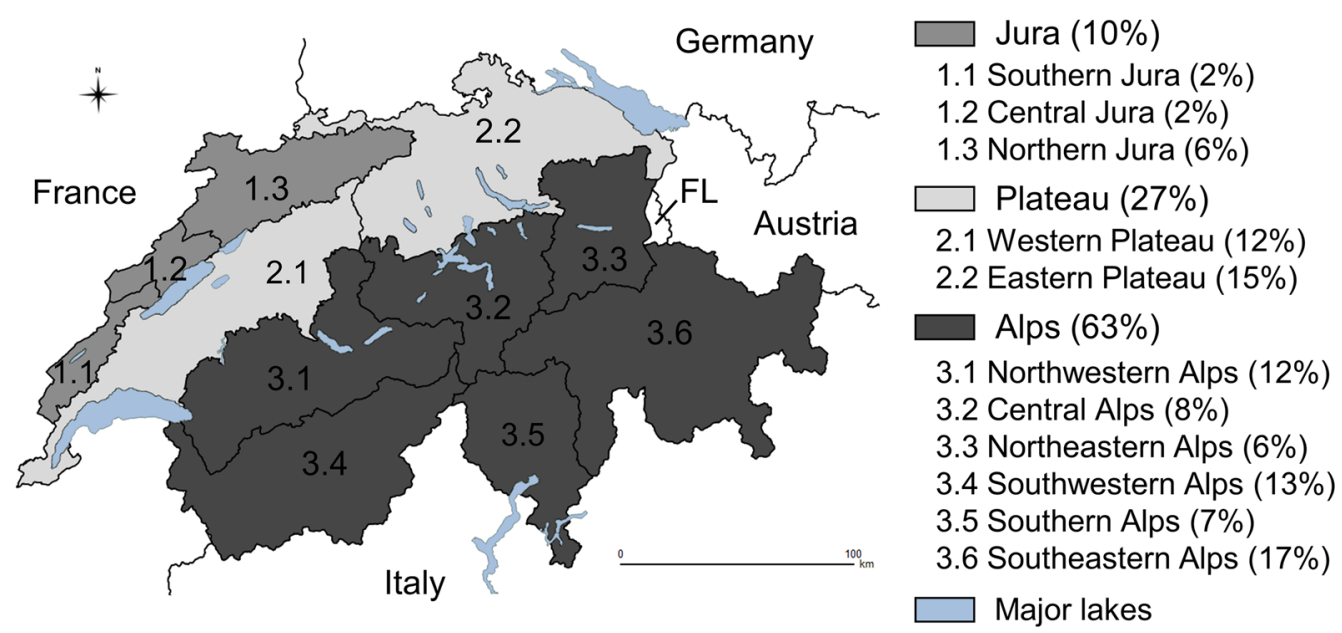

Fig. 1 Biogeographical regions and subregions of Switzerland. Shades of grey refer to the three biogeographical regions. Black lines border the eleven biogeographical subregions. The percentage of country surface area covered by the regions and subregions is given in brackets. Neighbouring countries are indicated with their names. Abbreviation: FL, Principality of Liechtenstein

\section{Study design}

Data obtained through the following five methods were combined: (i) a review of historical literature; (ii) screening of necropsy reports from general health surveillance (1958-2018); (iii) compilation of data on sarcoptic mange (1968-1992) collected during the sylvatic rabies eradication campaign; (iv) a questionnaire survey $(<1980-$ 2017); and (v) evaluation of camera-trap bycatch data (2005-2018).

\section{Review of the historical literature}

The aim of the literature review was to discover the oldest mention of MLL in foxes in Switzerland and in neighbouring countries. The following online databases were consulted: PubMed (http://www.ncbi.nlm.nih. gov/pubmed/), Google Books (http://www.books.googl e.com) Google Scholar (http://www.scholar.google.com), Zobodat (http://www.zobodat.at), Gallica (http://www. gallica.bnf.fr), E-periodica (http://www.e-periodica.ch), E-rara (http://www.e-rara.ch), E-manuscripta (http:// www.e-manuscripta.ch), the Swiss National Library (http://www.nb.admin.ch) and the Library of the Universities of Bern and Basel (http://www.baselbern.swissbib. ch). The following keywords were used in English, German, French and Italian: (i) sarcoptic mange (Sarcoptes scabiei, scabies, mange, itch, mite); (ii) red fox (Vulpes vulpes, fox); and (iii) Switzerland, Austria, Italy, France, Germany and Principality of Liechtenstein.

\section{General health surveillance}

In total, 1128 archived necropsy reports of foxes examined at the Centre for Fish and Wildlife Health (FIWI) between 1958 and 2018 (except for 1982: missing files) were screened for MLL and sarcoptic mange. The coordinates of origin were known for 1120 foxes (99\%). Based on the information included in the reports, animals were classified as juveniles ( $<6$ months-old) or subadults/ adults ( $\geq 6$ months-old), assuming the 1st of April as the date of birth of fox cubs [43]. Cases were placed in two 6-months periods (colder months: October-March and warmer months: April-September) according to their submission date.

Carcasses and organs of foxes of both sexes (558 males, 49\%; 505 females, 45\%; 65 of unknown sex, 6\%) and age classes (140 juveniles, 12\%; 933 subadults/adults, 83\%; 55 of unknown age, $5 \%$ ) were submitted from all biogeographical subregions, mostly from the Western Plateau (22\%), the Eastern Plateau (20\%) and the Northwestern Alps (19\%). A total of 694 foxes $(62 \%)$ had been culled, while 399 (35\%) animals were found dead. In 35 cases (3\%) there was no additional information about whether foxes had been found dead or culled. The number of performed necropsies (Fig. 2a) showed a similar pattern as the national hunting statistics (Fig. 2e; https://www.uzh. ch/wild/static/jagdstatistik/).

The method used for confirming S. scabiei infestation varied during the study period. From 1958 to 2003, deep dry skin scraping was used to isolate mites. Since 2004, isolation of mites has been attempted through a heating stimulation technique (i.e. skin samples placed in Petri dishes under a light source) and/or deep dry skin scraping $[4,44]$. Identification of S. scabiei was performed through morphological characterization using a light microscope 


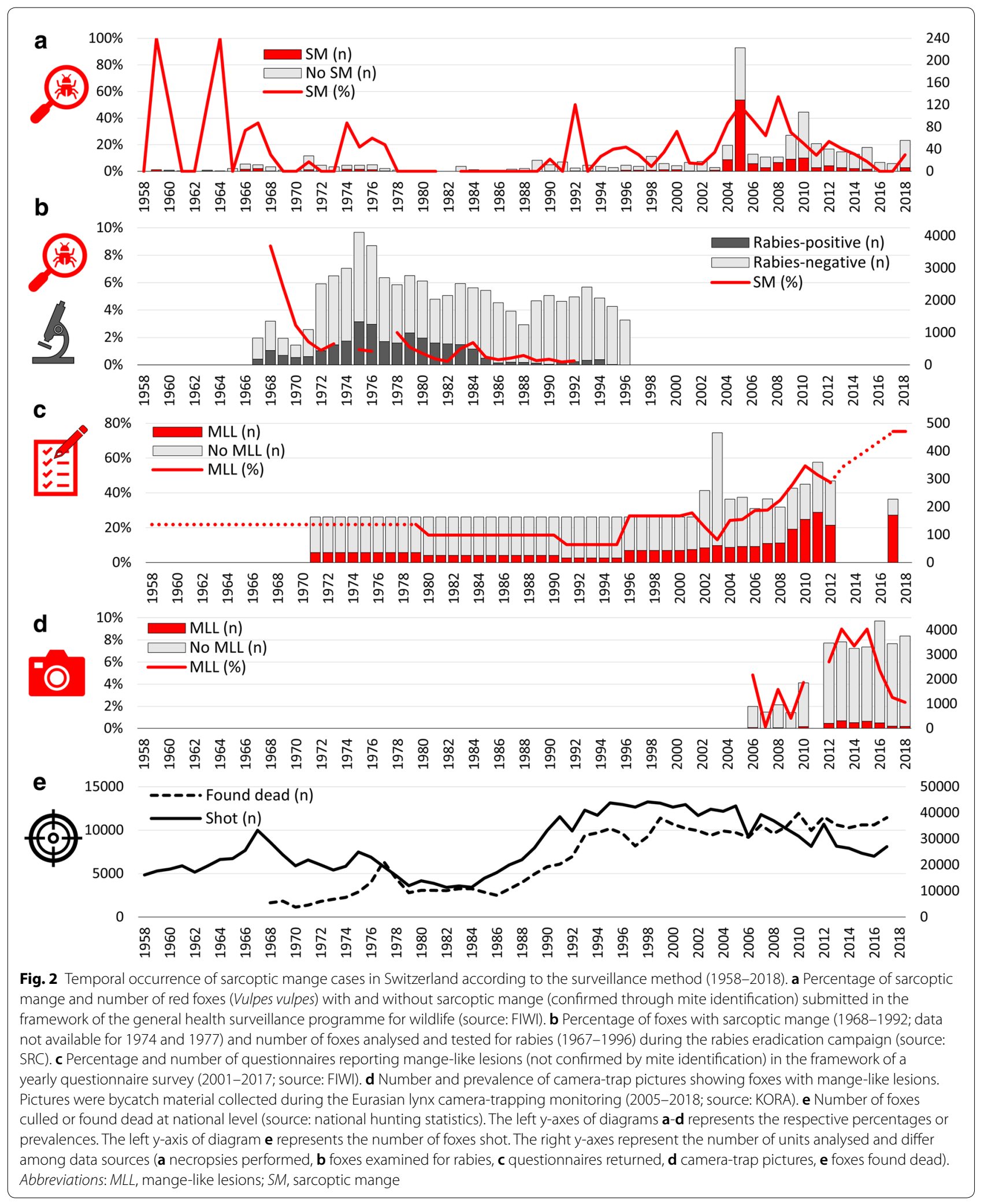


[45]. If isolation failed, the presence of intradermal mites was investigated through histopathology [46].

Carcass collection intensity and the institutions involved varied throughout the study period: during the rabies epidemic peak (1970-1980s [47]), foxes were sent to the Swiss Rabies Centre (SRC) rather than to the FIWI. From 2002 to 2013, questionnaire participants (see below) were reminded each year to submit foxes with MLL to the FIWI for post-mortem examination to validate the data obtained through the questionnaire survey. In 2004-2005, foxes with MLL were actively collected for a study on sarcoptic mange [4]. Since 2009, an increased number of foxes have been submitted due to epidemic waves of canine distemper [48, 49].

\section{Data on mange collected during the sylvatic rabies eradication campaign}

Archival data on sarcoptic mange (MLL with confirmed S. scabiei infestation) collected on foxes tested for rabies at the SRC from 1968 to 1992 (except for 1974 and 1977: missing reports on mange) were screened $(n=29,241$; database of the SRC). Coordinates of mangy foxes were only available for foxes submitted from 1968 to 1990 . Mite isolation was attempted through deep skin scraping and microscopic characterization. The number and geographical origin of foxes tested positive for rabies from 1967 to 1996 (last case of rabies in a fox [50]) were illustrated to help the interpretation of the data on sarcoptic mange (Figs. 2b, 3; database of the SRC $[47,51]$ ).

\section{Questionnaire survey}

A questionnaire was sent to professional game wardens and hunters responsible for a district of surveillance (i.e. wildlife management subunits) every year from 2002 to 2013 and again in 2018 (12 survey rounds in total). The questionnaire gathered information about the observation of foxes with MLL in the respective districts during the previous year (i.e. 2001-2012 and 2017) and consisted in four closed questions (Table 1). In the first survey round (2002) an additional question was included on MLL occurrence in previous decades (before 1980, 19801990, 1991-1995, 1996-2000).

Questionnaires were filled either by the cantonal hunting office for the entire canton or by the persons in charge of the single districts, resulting in different numbers of returned questionnaires per canton and per year. In total, 4054 exploitable questionnaires were returned to the FIWI. The answers were aggregated in nine time periods (before 1980, 1980-1990, 1990-1995, 1996-2000, 20012003, 2004-2006, 2007-2009, 2010-2012 and 2017). The lowest number of foxes with MLL reported yearly as a range was calculated by adding the lowest value of the answers of the second question of the questionnaire (i.e. how many foxes were affected, indicated as a range). The mean of these values was calculated for each period. MLL occurrence was expressed as the percentage of responding cantons and districts reporting MLL and as the percentage of CSA covered by districts reporting MLL, in an attempt to quantify the spatial spread of sarcoptic mange.

\section{Camera-trapping}

Pictures of foxes collected as bycatch data in the framework of a long-term camera-trap monitoring programme for the Eurasian lynx conducted by KORA (Carnivore Ecology and Wildlife Management) were assessed for the presence of MLL in foxes. The monitoring was standardized and performed during 23 sessions. Each session generated data recorded during subsequent 60 days between 2005 and 2018 in seven sectors belonging to six subregions (Additional file 1: Table S1) using Xenon white flash camera-traps with a fast trigger speed to produce high quality pictures [52, 53]. Because each session was performed in winter, either from December to February (phase 1) or from February to April (phase 2), the year used to designate a session corresponded to the year when the session ended (Additional file 1: Table S1). In total, 69,116 pictures were obtained and evaluated.

In a first step, all pictures of foxes $(n=30,168,44 \%)$ were screened for the presence of MLL by KORA collaborators. In a second step, 7421 of these pictures were randomly selected and re-assessed for MLL by a wildlife veterinarian (first author); the original assessment was masked to ensure an objective re-evaluation. Cohen's kappa was computed to assess inter-observer agreement between the two evaluations [54]. According to the Cohen's kappa test value (Cohen's kappa: $k=0.8$; $Z=68.6 ; P<0.0001$; see Data analyses section below), the KORA evaluation was considered sufficient for the calculation of the MLL prevalence using all fox pictures of the database. For each session, MLL prevalence was estimated at picture level: number of pictures of foxes with MLL/total number of fox pictures.

\section{Hunting statistics}

The national and cantonal hunting bags and the number of foxes found dead from 1958 to 2017 were obtained from the free-access website of the national hunting statistics: https://www.uzh.ch/wild/static/jagdstatistik/. Normalized hunting bags in relation to the preferred habitat of foxes (HIPD: hunting indicator of fox population density, i.e. number of foxes shot/terrestrial surface $\left(\mathrm{km}^{2}\right)$ below 2000 meters of altitude [55]) were used as an index of fox density in the respective areas [56]. The cantonal HIPDs during four 4-year periods (before, 1946-1950; during, 1980-1984; and after the rabies epidemics, 19931997 and 2013-2017), the respective factor of increase 

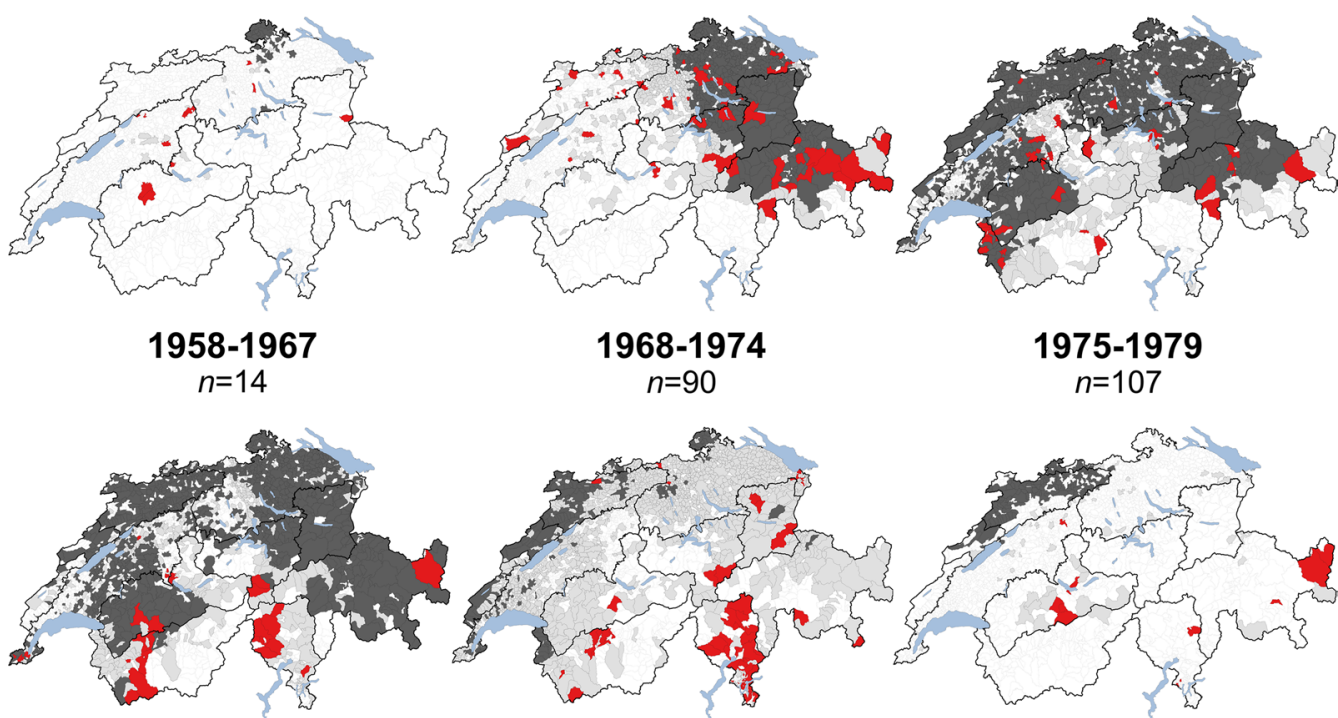
1975-1979
$n=107$

\section{0-1984}

$n=44$

$1985-1990$

$n=56$

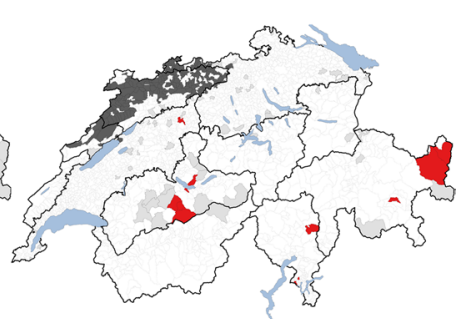

1991-2000

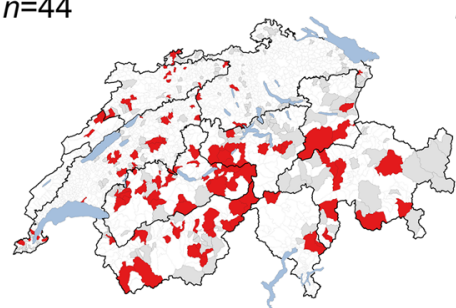

2001-2010

$n=204$ $n=12$

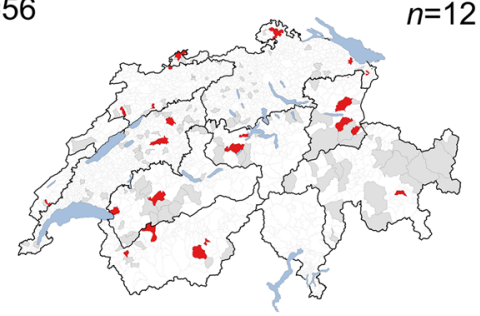

2011-2018

\section{Sarcoptic mange \\ No sarcoptic mange, rabies-positive \\ Lakes}

No foxes submitted

No sarcoptic mange, rabies-negative

Fig. 3 Spatiotemporal distribution of red foxes with sarcoptic mange in Switzerland (1958-2018). Municipalities from where red foxes (Vulpes vulpes) were submitted in the framework of the general health surveillance programme for wildlife (1958-2018; source: FIWI) and during the initial part of the rabies eradication campaign (1968-1990; data on mange not available for 1974 and 1977; source: SRC) are illustrated with different colours depending on whether foxes had sarcoptic mange or not and whether they were tested positive or negative for rabies. Sarcoptic mange was defined as the presence of mange-like lesions confirmed by the detection of Sarcoptes scabiei. In the periods 1958-1967, 1991-2000, 20012010, 2011-2018 only the municipalities with rabies occurrence (data on mange not available; source: SRC) and those without rabies analysed at the FIWI (data on mange available) were illustrated. The total number of foxes with sarcoptic mange is indicated below the corresponding period

Table 1 Questions (and possible answers) of the yearly questionnaire survey on sarcoptic mange in red foxes in Switzerland

\begin{tabular}{|c|c|c|c|c|c|c|}
\hline \multicolumn{2}{|c|}{ Questions } & \multicolumn{5}{|l|}{ Answers } \\
\hline 1 & Did you observe foxes with MLL? & Yes & No & - & - & - \\
\hline 2 & How many foxes were affected? & None & $1-2$ & $3-5$ & $6-10$ & $>10$ \\
\hline 3 & $\begin{array}{l}\text { If you observed cases, which type(s) of observation } \\
\text { did you make? }\end{array}$ & Live fox(es) with MLL & $\begin{array}{l}\text { Fox(es) found } \\
\text { dead with } \\
\text { MLL }\end{array}$ & Culled fox(es) with MLL & $\begin{array}{l}\text { Mite detection } \\
\text { in a laboratory }\end{array}$ & - \\
\hline 4 & How do you consider the trend of MLL occurrence & Increasing & Stable & Decreasing & - & - \\
\hline
\end{tabular}

Abbreviation: MLL, mange-like lesions 
(e.g. $\left.\mathrm{HIPD}_{80-84} / \mathrm{HIPD}_{46-50}\right)$ and rate of increase, e.g. $\left(\mathrm{HIPD}_{80-84}-\mathrm{HIPD}_{46-50}\right) /(34$ years $\times 100)$ were calculated according to Müller et al. [56] and used to help the interpretation of the sarcoptic mange trends. These data have already been used in other studies to detect the effect of rabies on fox population in Switzerland $[43,56]$.

\section{Data analyses}

Data management and descriptive statistics were conducted in Microsoft Excel and Access 2016 (Microsoft Corporation, Redmond, Washington, USA). Statistical analyses were performed with $\mathrm{R}$ version 3.4 .3 (http:// www.r-project.org). The prevalence package was used to calculate prevalence with a Clopper-Pearson confidence interval (CI) of 95\% (propCI function). Prevalences were calculated only for the camera-trapping data because the reference population was the entire fox population living in the assessed sector (in contrast to the collection of diseased foxes selected by field partners). Cohen's kappa was computed using the irr package [54]. The exact binomial test (binom.test function) was used to compare sex and age of fox carcasses submitted to the FIWI. The test of equal or given proportions (TEP, prop.test function) and the pairwise comparisons for proportions with HolmBonferroni adjustment method (pairwise.prop.test function) were computed to compare percentages and prevalences. The level of significance was set at $P<0.05$. Maps were designed using qGIS version 2.18.5 (http:// www.qgis.org). The percentages of CSA covered by districts or municipalities with or without mange occurrence were obtained in qGIS.

\section{Results}

\section{Review of the historical literature}

The oldest document mentioning mange in foxes in Switzerland was a book on fox diseases published in 1835 [57]. In neighbouring countries, mange in foxes was mentioned in a human medical book published in Italy in 1560 [58], in a French forensic medicine and public health book from 1813 [59], in a German natural history newspaper from 1772 [60] and in a natural history book published in Austria in 1855 [61]. Although no historical information on mange for the Principality of Liechtenstein was found, sarcoptic mange has been present in the fox population of this country at least since 2012 (FIWI archives, unpublished observation).

\section{General health surveillance}

The oldest case of confirmed sarcoptic mange dates back to 1959 and originated from the Northwestern Alps. MLL were detected in 326 (29\%) foxes (51\% males; $45 \%$ females; $4 \%$ unknown sex). Intradermal mites consistent with S. scabiei were found in 278 (85\%) foxes with MLL.
The percentage of foxes with confirmed sarcoptic mange did not significantly differ between males (26\%) and females (24\%, TEP: $\left.\chi^{2}=37844, d f=1, P=0.5384\right)$, while subadults/adults $(27 \%)$ were significantly more affected than juveniles (11\%; TEP: $\left.\chi^{2}=15.653, d f=1, P<0.0001\right)$. The percentage of MLL was significantly higher in foxes that were culled (35\%) than in foxes found dead $(20 \%$; TEP: $\left.\chi^{2}=26.546, d f=1, P<0.0001\right)$ and also higher in foxes that were submitted during the colder semester $(34 \%)$ than during the warmer semester (21\%; TEP: $\left.x^{2}=23.075, d f=1, P<0.0001\right)$. The monthly percentage of foxes with MLL is shown in Additional file 2: Figure S1. The highest MLL percentage was detected in December (57\%), the lowest MLL percentage in June (10\%).

The percentage and geographical distribution of foxes with MLL (with or without mite detection) varied over the entire study period (Table 2, Figs. 2a, 3; Additional file 2: Tables S3 and S4, Figures S2-S4). Foxes with confirmed sarcoptic mange were mostly submitted from the Northwestern Alps (33\%), Western Plateau (17\%) and Southwestern Alps (16\%; Fig. 3, Additional file 2: Figure S4).

\section{Data on mange collected during the rabies eradication campaign}

Sarcoptic mange was reported in 306 (1\%) foxes. Mangy foxes were submitted from all subregions but mainly from the Southern Alps (31\%), the Eastern Plateau (15\%) and the Southwestern Alps (13\%), and only rarely from the Jura (Fig. 3, Additional file 3: Table S5).

The percentage and distribution of foxes with sarcoptic mange varied with the occurrence and spread of rabies. The percentage rapidly decreased as the cumulative percentage of CSA with rabies occurrence increased, decreasing in the biogeographical subregions where rabies occurred, showing a similar pattern as the national hunting statistics (Figs. 2b, 3, Additional file 3: Figures S5-S7). More precisely, the percentage of sarcoptic mange was higher in the Southern (29\%) and Southwestern (4\%) Alps, where rabies only minimally spread due to the successful vaccination campaigns or had never occurred, respectively (Fig. 3, Additional file 3: Table S5, Figure S6) [51]. The percentage of sarcoptic mange significantly decreased from $1 \%(1968-1984)$ to $0.2 \%$ (1985-1992; TEP: $\left.\chi^{2}=114.06, d f=1, P<0.0001\right)$ in all subregions except the Southern Alps, where the percentage $(25 \%)$ was significantly higher during the same period (1985-1992; TEP: $\chi^{2}=2118, d f=1, P<0.0001$; Additional file 3: Figure S7).

\section{Questionnaire survey}

In total, MLL were reported in 1358 (34\%) returned questionnaires. Detailed information on the results of the 
Table 2 Spatiotemporal distribution of foxes with mange-like lesions from 1958 to 2018. Affected foxes (Vulpes vulpes) with mangelike lesions submitted from three biogeographical regions and eleven subregions in the framework of the general health surveillance programme for wildlife in Switzerland. Percentage (\%) followed by the number of foxes affected/examined in parentheses

\begin{tabular}{lllllllll}
\hline (Sub)region & & $1958-1969$ & $1970-1979$ & $1980-1989$ & $1990-1999$ & $2000-2009$ & $2010-2018$ & Total \\
\hline 1 & Jura & $40(2 / 5)$ & $14(2 / 14)$ & $0(0 / 9)$ & $0(0 / 15)$ & $33(13 / 39)$ & $38(14 / 37)$ & $26(31 / 119)$ \\
1.1 & Southern Jura & nd & nd & nd & nd & nd & $50(1 / 2)$ & $50(1 / 2)$ \\
1.2 & Central Jura & nd & nd & $0(0 / 1)$ & $0(0 / 1)$ & $50(2 / 4)$ & $0(0 / 1)$ & $29(2 / 7)$ \\
1.3 & Northern Jura & $40(2 / 5)$ & $14(2 / 14)$ & $0(0 / 8)$ & $0(0 / 14)$ & $31(11 / 35)$ & $38(13 / 34)$ & $25(28 / 110)$ \\
2 & Plateau & $31(9 / 29)$ & $22(6 / 27)$ & $0(0 / 13)$ & $5(3 / 56)$ & $24(36 / 153)$ & $15(28 / 181)$ & $18(83 / 459)$ \\
2.1 & Western Plateau & $33(6 / 18)$ & $24(6 / 25)$ & $0(0 / 9)$ & $3(1 / 29)$ & $28(31 / 110)$ & $14(7 / 49)$ & $22(51 / 240)$ \\
2.2 & Eastern Plateau & $27(3 / 11)$ & $0(0 / 2)$ & $0(0 / 4)$ & $7(20 / 27)$ & $12(5 / 43)$ & $16(21 / 132)$ & $22(49 / 219)$ \\
3 & Alps & $67(6 / 9)$ & $18(8 / 45)$ & $0(0 / 13)$ & $28(11 / 40)$ & $61(167 / 276)$ & $13(21 / 159)$ & $39(214 / 542)$ \\
3.1 & Northwestern Alps & $63(5 / 8)$ & $29(2 / 7)$ & $0(0 / 10)$ & $22(6 / 27)$ & $71(88 / 124)$ & $8(3 / 36)$ & $49(104 / 212)$ \\
3.2 & Central Alps & nd & nd & $0(0 / 1)$ & nd & $55(12 / 22)$ & $17(5 / 30)$ & $32(17 / 53)$ \\
3.3 & Northeastern Alps & $100(1 / 1)$ & nd & $0(0 / 1)$ & $0(0 / 2)$ & $7(1 / 15)$ & $39(7 / 18)$ & $24(9 / 37)$ \\
3.4 & Southwestern Alps & nd & nd & nd & $0.0(0 / 1)$ & $65(50 / 77)$ & $24(4 / 17)$ & $57(54 / 95)$ \\
3.5 & Southern Alps & nd & nd & $0(0 / 1)$ & $67(2 / 3)$ & $83(5 / 6)$ & $0(0 / 3)$ & $54(7 / 13)$ \\
3.6 & Southeastern Alps & nd & $16(6 / 38)$ & nd & $43(3 / 7)$ & $34(11 / 32)$ & $4(2 / 55)$ & $17(22 / 132)$ \\
Switzerland & & $40(17 / 43)$ & $19(16 / 86)$ & $0(0 / 35)$ & $13(14 / 111)$ & $46(216 / 468)$ & $17(63 / 377)$ & $30(326 / 1120)$
\end{tabular}

Abbreviation: nd: no data

Table 3 Occurrence of foxes with mange-like lesions based on a multi-year questionnaire survey in Switzerland. Percentage (\%) followed, in parentheses, by the number of districts of surveillance, cantons and subregions reporting red foxes (Vulpes vulpes) with mange-like lesions/number of responding districts of surveillance, cantons and subregions

\begin{tabular}{llllllllll}
\hline & $<1980$ & $1980-1990$ & $1991-1995$ & $1996-2000$ & $2001-2003$ & $2004-2006$ & $2007-2009$ & $2010-2012$ & 2017 \\
\hline Districts of surveillance & $22(36 / 162)$ & $16(26 / 162)$ & $10(17 / 162)$ & $27(44 / 162)$ & $18(157 / 884)$ & $26(169 / 653)$ & $37(258 / 691)$ & $50(471 / 933)$ & $75(171 / 227)$ \\
Cantons & $58(14 / 24)$ & $33(8 / 24)$ & $17(4 / 24)$ & $50(12 / 24)$ & $50(13 / 26)$ & $58(14 / 24)$ & $68(17 / 25)$ & $91(21 / 23)$ & $96(25 / 26)$ \\
Subregions & $100(10 / 10)$ & $80(8 / 10)$ & $60(6 / 10)$ & $81(9 / 11)$ & $72(8 / 11)$ & $81(9 / 11)$ & $100(11 / 11)$ & $100(11 / 11)$ & $100(11 / 11)$ \\
\hline
\end{tabular}

questionnaire survey are summarized in Additional file 4: Tables S6 and S7.

Before 1980, foxes with MLL were reported only in a few isolated, non-adjacent districts in all investigated subregions (20\% CSA) (Table 3, Fig. 4, Additional file 4: Figures S8 and S9). The reports of foxes with MLL dropped from 1980 to 1995 and originated mainly from the Southwestern Alps (9-12\% CSA), while only a few isolated reports came from the remaining Alpine subregions, from the Western Plateau and the Northern Jura (Table 3, Fig. 4, Additional file 4: Figures S8 and S9). From 1996, the number of reports increased again $(21 \%$ CSA) and foxes with MLL were reported mainly from the Southwestern and Southern Alps and less frequently from the Northwestern and Central Alps (Table 3, Fig. 4, Additional file 4: Figures S8 and S9).

From 2001 to 2017, the number and percentage of responding cantons and districts of surveillance reporting foxes with MLL, the corresponding CSA percentage and the total number of foxes with MLL continuously increased (Table 3, Fig. 4, Additional file 4: Figure S8 and
S9). In 2001-2003, the distribution pattern was similar to that of the previous period (1996-2000), but the mange front moved slightly further north: the number of districts with mange occurrence increased both in the Northwestern and Southwestern Alps and in the Western Plateau (Fig. 4). In the Northern Jura, there was a slight increase of districts with only a few observations of foxes with MLL (Fig. 4, Additional file 4: Figure S10). In 20042006, MLL were again mainly reported from the southern half of the country, but the spread slowly continued towards north, especially in the Western Plateau (Fig. 4). Sarcoptic mange was confirmed and further spread in the Northern Jura (Fig. 4, Additional file 4: Figure S10). The situation in the Northeastern and Eastern Alps and in the Jura remained unchanged, with only a few unconfirmed reports (Fig. 4, Additional file 4: Figure S10). In 20072009, mange spread further north in the western part of Switzerland and further south in the eastern part of Switzerland. Since 2008, the Northwestern, Southwestern and Southern Alps, most of the Western Plateau, Southern Jura, Central Jura and Southeastern Alps have been 

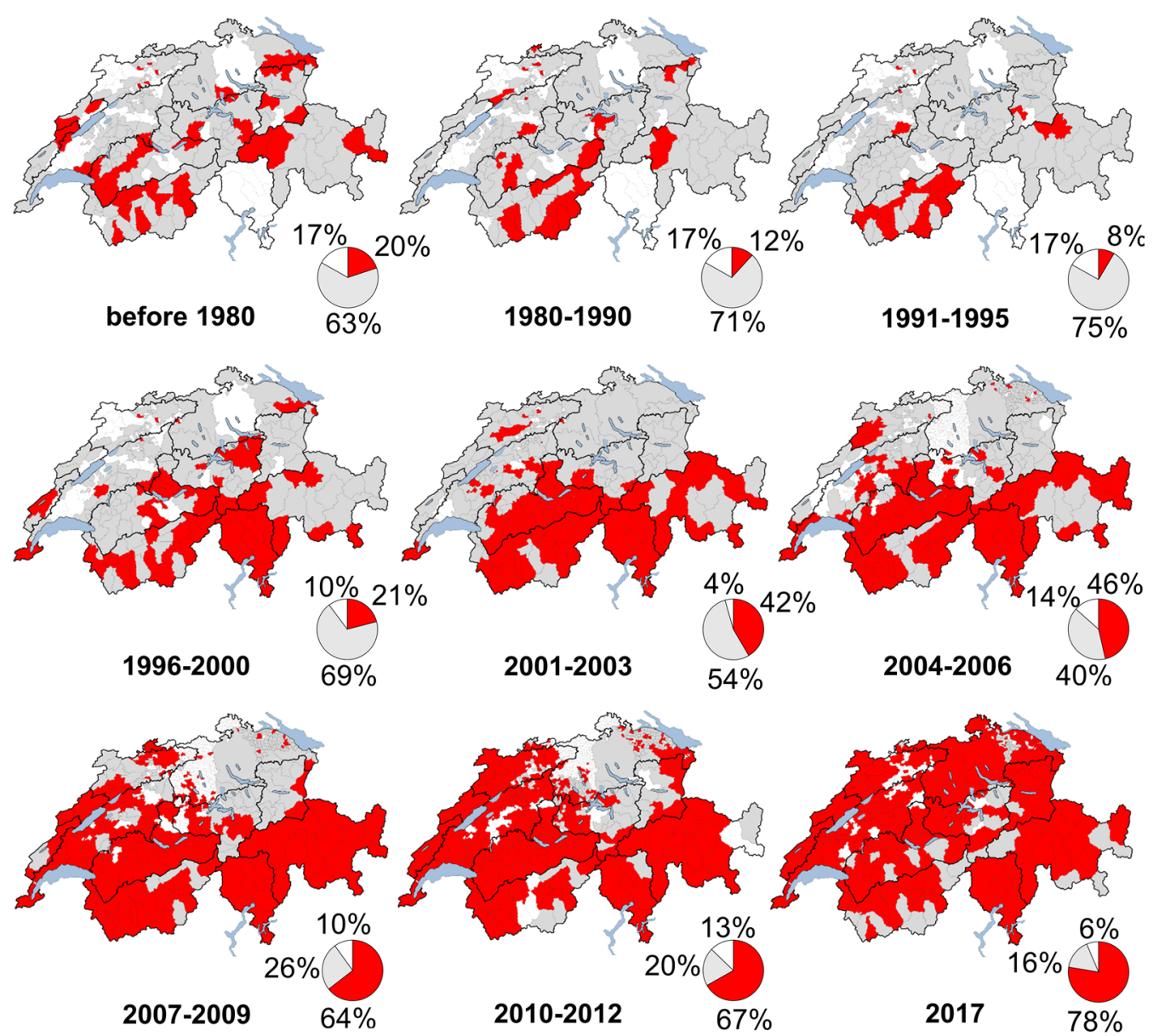

MLL

No MLL

No answer

Major lakes

Fig. 4 Spatiotemporal distribution of red foxes with mange-like lesions based on a multi-year questionnaire survey. The maps illustrate the districts of surveillance in Switzerland reporting foxes (Vulpes vulpes) with and without mange-like lesions per period. Pie charts represent the total country surface area of Switzerland and show the percentage of the total area corresponding to districts with reported occurrence or absence of mange-like lesions in foxes, or which did not reply to the questionnaire survey. Biogeographical subregions are delimited by black lines. Abbreviation: MLL, mange-like lesions

entirely affected (Fig. 4). An increase of observations also came from the Northern Jura and cases were reported from the Northeastern Alps for the first time since the 1991-1995 period (Fig. 4, Additional file 4: Figure S10). On the contrary, in the Central Alps the spread was less pronounced, and the Eastern Plateau was still largely free of mange (Fig. 4). In 2010-2012, mange spread further in the northwestern and northeastern parts of Switzerland and MLL were reported from all of Switzerland except for the central part of the Eastern Plateau, the western part of the Eastern Alps and most of the Central Alps (Fig. 4). In 2017, the spread over the country was nearly complete: most of the districts reported MLL, especially in the Jura and in the Plateau (Fig. 4, Additional file 4: Figure S10). At the same time, an increased number of districts (mainly in the Alps) did not report foxes with MLL anymore, suggesting a local fading out of the epidemic (Fig. 4, Additional file 4: Figure S11).

The apparent discrepancy between the increase of foxes with MLL reported by questionnaire and the relative decrease of submission of mangy foxes in the framework of general health surveillance (Figs. 2, 3, 4) is largely due to the end of the research project on mange in 2005 [4] and the consequent increased awareness for sarcoptic mange, which is relatively easy to recognize in the field. Field partners continued to report the occurrence of the disease in the questionnaire survey without sending foxes to the FIWI for post-mortem examination. 


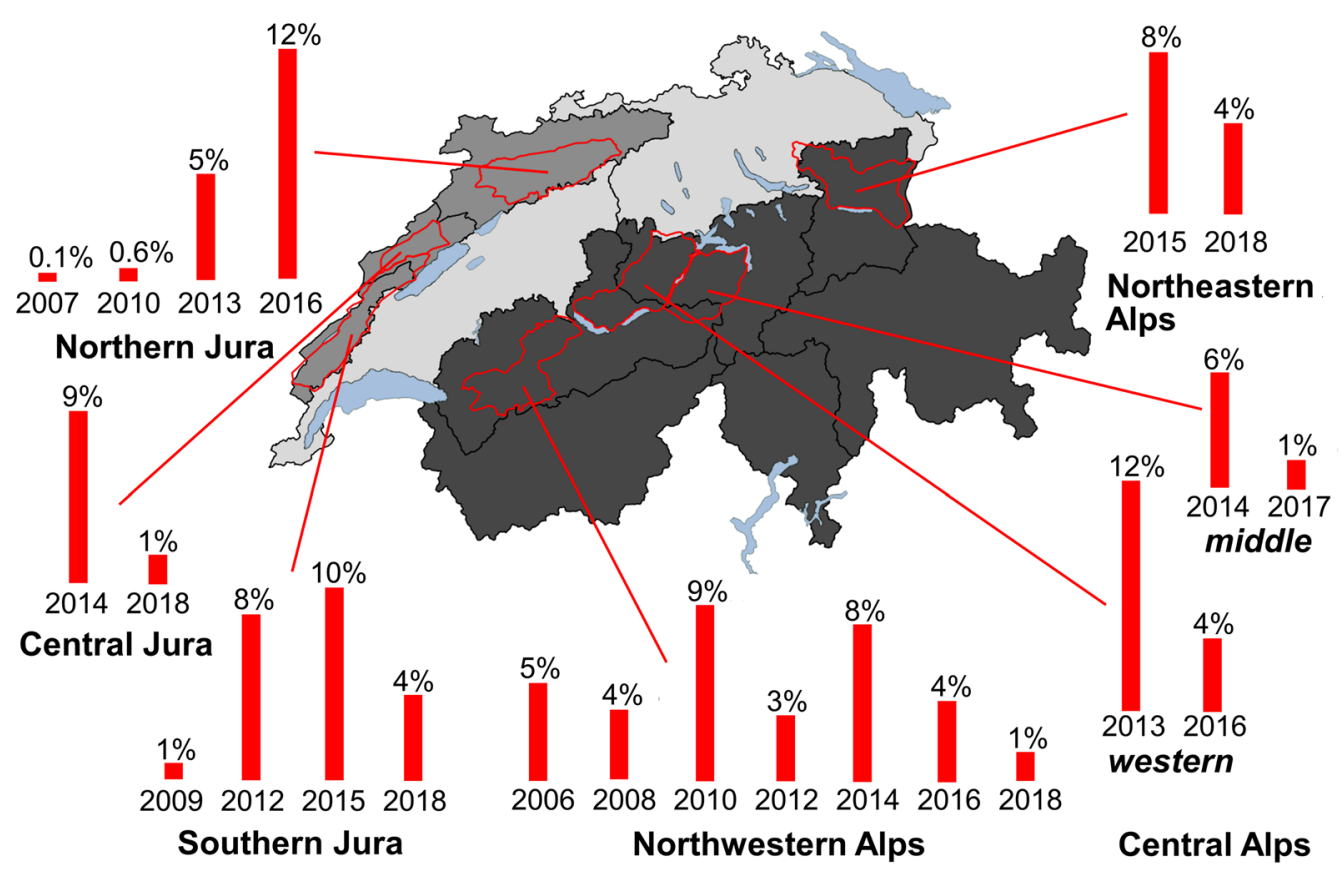

\section{MLL Prevalence $\square$ Camera-trapping sector $\square$ Jura $\square$ Plateau $\square$ Alps $\square$ Major lakes}

Fig. 5 Prevalence of mange-like lesions in red foxes estimated from camera-trap data from 2005 to 2018. The pictures of red foxes (Vulpes vulpes) used were bycatch material from camera-trapping work performed by KORA from 2005 to 2018. The prevalence of mange-like lesions is indicated for each of the 23 trapping sessions (one session $=60$ days in winter) in each of the 7 sectors considered for this study. Years indicated under the bars correspond to the year of the end of the session. Shades of grey refer to the three biogeographical regions. Biogeographical subregions are delimited by black lines. Abbreviation: MLL, mange-like lesions

\section{Camera-trapping}

MLL were recognizable in $6 \%$ of the fox pictures (Additional file 1: Table S2). In the Northwestern Alps sector, MLL prevalence showed a sinusoidal trend ranging from 1\% (95\% CI: 1-2\%) to 9\% (95\% CI: 8-12\%) between 2006 and 2018, suggesting an endemic situation (Fig. 5, Additional file 1: Table S2). The differences of MLL prevalence between pairs of successive sessions were almost all statistically significant (Additional file 1: Table S2). In the two Central Alps sectors, MLL prevalence decreased significantly from 6\% (95\% CI: 4-7\%) and 12\% (95\% CI: $10-13 \%)$ in $2013-2014$ to $1 \%$ (95\% CI: $1-2 \%$; TEP: $\left.\chi^{2}=36.086, d f=1, P<0.0001\right)$ and $4 \%$ (95\% CI: $3-5 \%$; TEP: $\left.\chi^{2}=92.84, d f=1, P<0.0001\right)$ in 2016-2017, respectively (Fig. 5, Additional file 1: Table S2). In the Northeastern Alps sector, MLL prevalence significantly decreased from 8\% (95\% CI: 7-9\%) in 2015 to $4 \%$ in 2018 (95\% CI: 3-6\%; TEP: $\chi^{2}=14.956, d f=1, P=0.00011$; Fig. 5, Additional file 1: Table S2).

In both the Northern and Southern Jura sectors, MLL prevalence remained very low $(0.1-1 \%, 95 \% \mathrm{CI}$ : $0-2 \%)$ from 2007 to 2010 (Fig. 5). From 2010 to 2016, MLL prevalence continuously increased in all three subregions of the Jura (Fig. 5, Additional file 1: Table S2), suggesting an epidemic. In the last session (2018), MLL prevalence dropped significantly in the Southern Jura (TEP: $\left.\chi^{2}=48.218, d f=1, P<0.0001\right)$ and the Central Jura sectors (TEP: $\chi^{2}=43.775, d f=1, P<0.0001$ ), suggesting a return to an endemic situation (Fig. 5, Additional file 1: Table S2).

\section{Hunting statistics}

The national hunting bag increased from 1958 to 1967, i.e. before the epidemic wave of rabies reached Switzerland, decreased then during the rabies epidemics until 1984, exponentially re-increased until the 1990s, largely above the pre-rabies level and has been moderately redecreasing since the mid-1990s (Fig. 2e, Additional file 2: Figure S2, Additional file 3: Figure S5, Additional file 5: Table S8). Similarly, the number of foxes found dead has continuously increased since 1968 (Fig. 2e), the year these data were recorded for the first time. During the pre-rabies phase, HIPDs were highest in the northeastern part of Switzerland and lowest in the central and southern parts of Switzerland (Additional file 5: Table S8). During the rabies epidemic, HIPDs decreased in cantons where rabies prevalence was higher and local rabies outbreaks lasted longer and where sarcoptic mange 
apparently disappeared (e.g. Jura, Plateau and Eastern Alps [50]; Additional file 5: Table S8). Following the rabies epidemics, HIPDs remained low in cantons where rabies did not arrive and sarcoptic mange did not disappear (part of the Alps) but had increased again in cantons where sarcoptic mange re-emerged and spread further (Jura and Plateau; Additional file 5: Table S8).

\section{Discussion}

In this study, a multi-method approach was used to describe the spatiotemporal pattern of spread of sarcoptic mange in foxes in Switzerland since the 19th century. In relation to the massive sylvatic rabies epidemic that spread through Europe in the second half of the 20th century [62, 63], long-term dynamics of sarcoptic mange in Switzerland can be roughly subdivided into three phases: (i) pre-rabies (until the 1960s); (ii) rabies epidemic peak (1970s-1980s); and (iii) post-rabies peak (1990s-2010s), i.e. phase-out (until 1997) and post-eradication (from 1999 onwards). Sarcoptic mange has been present in free-ranging wildlife for decades and perhaps even centuries in Switzerland, in agreement with previous reports $[11,57,64,65]$. The widespread distribution of sarcoptic mange in a few isolated districts or municipalities before the arrival of rabies is consistent with an endemic situation, as previously mentioned [57, 65-68]. Rabies entered the northeastern part of Switzerland in 1967 and subsequently spread further as a large closed front wave over almost the northmost half of the country, especially over the Jura and the Plateau (Fig. 3) [51]. Since then, awareness, surveillance efforts and research interest for sarcoptic mange increased resulting in an improved data accuracy and finer scale resolution. The disease became less common and apparently disappeared ("hypoendemic" situation) in subregions with rabies occurrence but largely persisted in the subregions without rabies occurrence (Southern Alps, Southwestern Alps, parts of the Central Alps). In the post-rabies peak phase, sarcoptic mange re-emerged where it had apparently disappeared and spread epidemically until occurring in almost all of the country. The epidemic front of sarcoptic mange seemed to move from the Alps towards the Jura following the "retreat line" of rabies. Since the mid-2010s, a mosaic of endemic and epidemic situations has been observed in the most recently affected subregions (rest of the Alps, Plateau and Jura). Therefore, in contrast to the perception in the late 1990s, sarcoptic mange did not newly emerge in Switzerland but, rather, re-emerged especially in the Northwestern and Central Alps.

The findings of this study suggest a series of epidemiological transitions: from an endemic to a "hypoendemic" and epidemic situation first and from an epidemic back to a partially endemic situation then. Patterns of disease spread are multifactorial and therefore difficult to be completely elucidated, especially in a highly adaptable species such as the red fox (e.g. [69]). Influencing factors may include variations in host population density, host population dynamics, social, behavioural and spatial ecology (including dispersal, migration and changes in home range sizes), as well as by various other factors including landscape structure, environmental and climatic factors, host(s) life history, and host and pathogen genetic diversity [11, 70-74]. It can be hypothesised that the described epidemiological transitions may have been eased by three successive processes.

First, rabies epidemic and related control interventions (e.g. increased hunting pressure and den gassing) led to a demographic bottleneck characterized by a fox population decline of up to $80-90 \%[43,50,75,76]$ in parallel to a strong reduction or even apparent disappearance of sarcoptic mange. Demographic bottlenecks and population separations may lead to a decrease of genetic diversity [77]. This may limit the adaptive potential of populations to pathogens $[78,79]$ and, in turn, influence disease dynamics and increase vulnerability to diseases [80, 81]. The fox population collapse (already denominated as "rabies pit" [56]) in the Plateau and the Jura may have impaired, on the one hand, the transmission of S. scabiei due to the reduced density and therefore contacts among foxes and, on the other hand, removed diseased and also resistant individuals, disrupting the long-term host-parasite adaptation and generating a susceptible "naïve-like" population. At the same time, sarcoptic mange persisted endemically in most Alpine subregions, where local fox population may have acted as a reservoir for S. scabiei. In these subregions, HIPDs had been lowest since the 1930s [56] and pressure of rabies and related management measures were less important or not existing at all [51].

Secondly, sarcoptic mange re-emerged and spread with an epidemic wave during and after rabies eradication. The reason for this is likely multifactorial and difficult to analyse without a modelling approach. On the one hand, following the successful oral vaccination campaigns initiated in 1978, rabies was progressively eliminated $[47,50]$ and the fox population recovered as suggested by the large increase of the national hunting bag and roadkill numbers $[43,56]$. The increased density of the mostly "naïve-like" fox population may have facilitated contacts among animals and therefore the transmission of S. scabiei, i.e. a local re-emergence of the disease. This increase of population density (as suggested by the HIPDs) has been most prominent in the Plateau and in the Jura, where rabies had persisted longest and therefore rabies-related mortality had been highest $[50,56]$ and where sarcoptic mange had apparently disappeared but finally re-emerged and further spread. The limited to 
absent increase of the HIPDs in the Southern, Central, Southeastern and Southwestern Alps [56], where sarcoptic mange has persisted endemically, may have been due to the low or absent rabies-related mortality and a lower carrying capacity than in the Jura and Plateau [56]. On the other hand, the occasional movement of infected animals to naïve-like subpopulations, e.g. through dispersal, could explain the observed epidemic wave. Since food availability and possibly the fox population density are lower in the Alps, home range sizes may be larger but overlap less than in the Jura and the Plateau $[55,69,82]$. Assuming negative density dependent dispersal in foxes $[43,83]$, more juvenile foxes would leave their natal range and those that disperse would move over longer distances in the affected Alpine subregions (lower density) than in the Plateau and the Jura (higher density). As a result, the prevalence of sarcoptic mange likely increased while the spread of the epidemic front decelerated in areas with higher fox densities such as the Plateau and the Jura. The observed pattern contrasts with the relatively rapid epidemic spread through Sweden, a country much larger than Switzerland, in the 1970s-1980s [84]. This difference is attributable to several factors. Compared to Sweden, food availability is likely higher in Switzerland, resulting in higher fox densities and smaller home ranges. Habitat fragmentation is also higher $[51,85]$ and in the 1980s foxes started to colonize human settlements including large Swiss cities [11, 86]. Although Alpine valleys represent separate epidemiologic compartments [63], occasional movements of mangy foxes over natural barriers may have occurred [51] and might have contributed to the spread of sarcoptic mange northwards [11]. Finally, climate change in Switzerland, characterized by the increase of yearly mean temperature, decrease of snow cover and fluctuations in the yearly precipitations since the 1980s [87], might have provided a suitable fox habitat at higher altitude, as it has been suspected in Italy [88], and influenced the ecology of S. scabiei.

Thirdly, while the epidemic spread was still ongoing in 2017-2018, especially in the Eastern Plateau, the disease may have already returned to an endemic status in subregions where it had re-emerged first, due to years of hostpathogen adaptation [89], i.e. through selection of more resistant individuals and some degree of immunity [21, 90]. This process may take a relatively long time to occur $[11,13,90,91]$, as reported for example in Scandinavia, where more than two decades were needed for sarcoptic mange to become endemic after its emergence and following epidemic spread [89].

Infectious diseases such as sarcoptic mange $[7,63$, 92], canine distemper [93-95] and rabies [76] can drive wild canid population dynamics by altering population size, growth rate, animal distribution, migration patterns and genetic diversity [96-98]. Studies on interactions between diseases $[99,100]$ in wildlife are rare, but comparable interactions between distemper and sarcoptic mange were hypothesized in wolves (Canis lupus) in the USA [95] and in Spain [101], while an association between genetic structure of fox population and infection with distemper and rabies was observed in Northern Italy [70]. This study suggests that rabies-related changes in the fox population dynamics affected the dynamics of sarcoptic mange, a phenomenon that has also recently been observed in Estonia [102-104].

A multi-method and a long-term approach were used to successfully compensate the limitations and exploit the advantages of different data sources, to cross-validate their results and to detect trends of disease dynamics that would have been misinterpreted or not recognized if shorter study periods had been considered [105]. All five data sources converged towards similar trends, complementing and overlapping each other, both geographically and in time. Improvement of wildlife disease surveillance has progressively delivered better information, demonstrating the relevance of wildlife health surveillance programmes to produce reliable information on wildlife disease epidemiology, which allows informed management decisions $[105,106]$.

Although the strength of this study lies in the combination of multiple data sources, each single method had limitations. The main limitation of the review of the historical literature included the difficulty to detect all existing documents due to lacking databases [107]. The use of HIPD is controversial but can be useful to evaluate longterm population trends in large areas [108, 109]. Limitations of the general health surveillance programme were, as already known for wildlife populations, the discovery, selection and submission of carcasses by field partners operating in different cantons, personnel changes and varying levels of disease awareness [6, 46, 105]. Sarcoptic mange can only be confirmed through isolation and identification of S. scabiei [109]. This was possible only for dead foxes submitted in the framework of the general health surveillance programme at the FIWI and of the rabies eradication campaign at the SRC. The other methods could only rely on MLL as indicator of sarcoptic mange (syndromic approach), which implies a risk of diagnostic error. However, rather typical skin lesions and confirmation of mites' presence in foxes submitted from affected locations strongly suggest that the observed MLL were (at least mostly) due to the spread of $S$. scabiei throughout the fox population. The data obtained in the context of the rabies eradication campaign provided the most representative and precise information about the spatiotemporal spread of sarcoptic mange but only 
during a relatively limited time-period (24 years) compared to the general health surveillance at the FIWI (60 years).

To our knowledge, this was the first long-term (almost 20 years) questionnaire survey on the occurrence of MLL worldwide. The advantage of repetitive assessments was the participation of experienced field partners, while main limitations were the size differences of the districts and the limited accuracy and representativeness of MLL reports before the first survey round (2001). Nevertheless, the strength of such surveys is that they are cheap, applicable to the whole country and easily repeatable. Although camera-trapping has already been used to detect MLL occurrence in wildlife $[19,110,111]$, this is the first long-term assessment (15 years) of mange occurrence using bycatch camera-trap pictures collected during repetitive sessions in selected sectors. This constancy allowed estimating MLL prevalence and its temporal trend. The data were precise at local level and, although not extrapolable to the entire country, they demonstrated clear differences among sectors. Detectability of MLL depends on many factors including characteristics and height of camera traps, image quality and behavioural changes in mangy foxes [11, 112, 113]. However, we expect that these aspects did not influence the detected trends as all sessions in a given camera-trapping sector would have been equally affected. The high time investment, material and personnel costs can limit the use of camera-trapping solely for monitoring MLL occurrence and highlight the utility of bycatch data for this use.

\section{Conclusions}

Sarcoptic mange in red foxes has likely been endemic in Switzerland as well as in other European countries at least since the mid-19th century. The rabies epidemics seem to have influenced the pattern of spread of mange in several locations, revealing an interesting example of disease interaction in free-ranging wildlife. This phenomenon may have been related to susceptibility changes in the population due to the disruption of the host-parasite co-evolution process within the fox population and to variation of animal numbers. The combination of multiple surveillance tools to study the long-term dynamics of sarcoptic mange in the red fox in Switzerland proved to be a successful investigation strategy. Considering the advantages and disadvantages of the applied methods, the cross-validation of the results indicate that a questionnaire survey is a particularly efficient and low-cost option to monitor the spatiotemporal spread of sarcoptic mange, assuming a uniform disease awareness and a good collaboration of field partners throughout the study area.

\section{Supplementary information}

Supplementary information accompanies this paper at https://doi. org/10.1186/s13071-019-3762-7.

Additional file 1: Table S1. Features of the camera-trapping monitoring.
Table S2. Overview of data obtained from 23 camera-trapping sessions.

Additional file 2: Table S3. Cantonal occurrence of sarcoptic mange in foxes examined in the framework of general health surveillance for wild life at the FIWI (1958-2018). Table S4. Yearly occurrence of sarcoptic mange in foxes examined at the FIWI. Figure S1. Monthly distribution of foxes with mange-like lesions examined at the FIWI. Figure S2. Number of foxes found dead and culled in Switzerland and of foxes examined per year at the FIWI. Figure S3. Number of foxes examined per period at the FIWI. Figure S4. Spatiotemporal distribution of foxes with sarcoptic mange examined at the FIWI (1958-2017).

Additional file 3: Table S5. Spatiotemporal distribution of foxes with sarcoptic mange and rabies (1967-1990). Figure S5. Foxes with sarcoptic mange analysed per year at the SRC. Figure S6. Spatiotemporal distribution of foxes with sarcoptic mange and/or rabies (1967-1990). Figure S7. Sarcoptic mange and rabies spread in Switzerland (1967-1992).

Additional file 4: Table S6. Answers to the questionnaire survey on sarcoptic mange in foxes per year (<1980-2017). Table S7. Answers to the questionnaire survey on sarcoptic mange in foxes per Swiss canton (<1980-2017). Figure S8. Changes in the occurrence of foxes with mange-like lesions in districts of surveillance per surface area. Figure s9. Temporal occurrence of mange-like lesions in foxes per number of cantons and districts of surveillance (questionnaire survey <1980-2017). Figure S10. Reliability categories of sarcoptic mange diagnosis in foxes (questionnaire survey 2001-2017). Figure S11. Trends in the occurrence of mange-like lesions in foxes in Switzerland (questionnaire survey 2001-2017).

Additional file 5: Table S8. Cantonal and national hunting statistics before, during and after the rabies epidemics.

\section{Abbreviations}

$\mathrm{Cl}$ : confidence interval; CSA: country surface area; FIWI: Centre for Fish and Wildlife Health; HIPD: hunting indicator of population density; MLL: mangelike lesions; SRC: Swiss Rabies Centre; TEP: test of equal proportions.

\section{Acknowledgements}

We thank the hunting offices of all Swiss cantons and their respective hunters and professional game-wardens for participating in the questionnaire survey and for submitting carcasses for post-mortem examination. We acknowledge the numerous KORA collaborators for the assessment of the camera-trap pictures. We thank Reto Zanoni for providing access to the database of the SRC and for the permission to use these data and, Andreas Kappeler and Alexander Wandeler for the collection of data about mangy foxes. Many thanks also go to Manuela Weber and Rebecca Hari (deceased) for their support with the data management of the questionnaire survey, to Nadia Robert and former pathologists for necropsy and histopathology supervision, to the numerous FIWI assistants who performed fox necropsies, to Urs Breitenmoser for his contribution to the interpretation of fox population dynamics and to Iris Marti for critical reading of the manuscript and support with statistical analyses.

\section{Authors' contributions}

MR, SP and FZ designed the study. SP performed the historical literature research. MR has coordinated the Swiss general wildlife health surveillance programme since 2002. MR and SC designed the questionnaire, implemented the yearly survey and the targeted collection of mangy foxes. MR, FZ, SC and SP carried out the multi-year questionnaire survey. FZ coordinated the camera-trap monitoring. RB and FK supervised camera-trapping data entry and checked for data integrity. EA compiled the data of the Swiss Rabies Centre (SRC). MR and FO supervised post-mortem examinations and mite identification. SP analysed all data. SP and MR drafted and finalized the manuscript. LR contributed to data interpretation and helped shaping the manuscript. All authors read and approved the final manuscript. 


\section{Funding}

The authors declare that they did not receive any funding specifically for this study. Photo-trapping was carried out in the framework of a mandate to KORA for the monitoring of Eurasian lynx in Switzerland. The questionnaire survey and all data analyses were done in the framework of the mandate to the FIWI for the surveillance of wildlife health in Switzerland. Both mandates were attributed and financially supported by the Swiss Federal Office of Environment.

\section{Availability of data and materials}

All relevant data are presented in the article. The original datasets are available from the corresponding author upon reasonable request.

\section{Ethics approval and consent to participate}

Not applicable.

\section{Consent for publication}

Not applicable.

\section{Competing interests}

The authors declare that they have no competing interests.

\section{Author details}

${ }^{1}$ Centre for Fish and Wildlife Health (FIWI), Department of Infectious Diseases and Pathobiology, Vetsuisse Faculty, University of Bern, Laenggassstrasse 122 PO Box, 3001 Bern, Switzerland. ${ }^{2}$ KORA - Carnivore Ecology and Wildlife Management, Thunstrasse 31, 3074 Muri, Switzerland. ${ }^{3}$ Dipartimento di Scienze Veterinarie, Università degli Studi di Torino, Largo Braccini 2, 10095 Grugliasco, Italy. ${ }^{4}$ Info Fauna, Swiss Centre for the Cartography of the Fauna, Bellevaux 51, 2000 Neuchâtel, Switzerland. ${ }^{5}$ Swiss Rabies Centre, Institute of Virology and Immunology (IVI), Vetsuisse Faculty, University of Bern, Laenggassstrasse 122, PO Box, 3001 Bern, Switzerland.

Received: 29 June 2019 Accepted: 22 October 2019

Published online: 05 November 2019

\section{References}

1. Pence DB, Ückermann E. Sarcoptic mange in wildlife. Rev Sci Tech. 2002;21:385-98.

2. Arlian LG, Morgan MS. A review of Sarcoptes scabiei: past, present and future. Parasit Vectors. 2017;10:297.

3. Oleaga A, Casais R, Prieto JM, Gortázar C, Balseiro A. Comparative pathological and immunohistochemical features of sarcoptic mange in five sympatric wildlife species in northern Spain. Eur J Wild Res. 2012;58:997-1000

4. Nimmervoll H, Hoby S, Robert N, Lommano E, Welle M, Ryser-Degiorgis M-P. Pathology of sarcoptic mange in red foxes (Vulpes vulpes): macroscopic and histologic characterization of three disease stages. J Wildl Dis. 2013:49:91-102.

5. Ryser-Degiorgis M-P, Ryser A, Bacciarini LN, Angst C, Gottstein B, Janovsky $M$, et al. Notoedric and sarcoptic mange in free-ranging lynx from Switzerland. J Wildl Dis. 2002;38:228-32.

6. Akdesir E, Origgi FC, Wimmershoff J, Frey J, Frey CF, Ryser-Degiorgis M-P. Causes of mortality and morbidity in free-ranging mustelids in Switzerland: necropsy data from over 50 years of general health surveillance. BMC Vet Res. 2018;14:195.

7. Mörner T. Sarcoptic mange in Swedish wildlife. Rev Sci Tech. 1992;11:1115-21.

8. Rentería-Solís Z, Min AM, Alasaad S, Müller K, Michler FU, Schmaschke $\mathrm{R}$, et al. Genetic epidemiology and pathology of raccoon-derived Sarcoptes mites from urban areas of Germany. Med Vet Entomol. 2014;28(Suppl. 1):98-103.

9. Süld K, Valdmann H, Laurimaa L, Soe E, Davison J, Saarma U. An invasive vector of zoonotic disease sustained by anthropogenic resources: the raccoon dog in northern Europe. PLoS ONE. 2014;9:e96358.

10. Astorga F, Carver S, Almberg ES, Sousa GR, Wingfield K, Niedringhaus $\mathrm{KD}$, et al. International meeting on sarcoptic mange in wildlife, June 2018, Blacksburg, Virginia, USA. Parasit Vectors. 2018;11:449.
11. Fischer $\mathrm{C}$. Effects of sarcoptic mange on the behaviour of the red fox and influence on other fox-borne zoonoses in Geneva, Switzerland. PhD Thesis, University of Lausanne; 2008.

12. Baker PJ, Funk SM, Harris S, White PCL. Flexible spatial organization of urban foxes, Vulpes vulpes, before and during an outbreak of sarcoptic mange. Anim Behav. 2000;59:127-46.

13. Soulsbury CD, lossa G, Baker PJ, Cole NC, Funk SM, Harris S. The impact of sarcoptic mange Sarcoptes scabiei on the British fox Vulpes vulpes population. Mammal Rev. 2007:37:278-96.

14. Forchhammer MC, Asferg T. Invading parasites cause a structural shift in red fox dynamics. Proc Biol Sci. 2000;267:779-86.

15. León-Vizcaino L, Ruíz de Ybáñez MR, Cubero MJ, Ortíz JM, Espinosa J, Pérez $L$, et al. Sarcoptic mange in Spanish ibex from Spain. J Wildl Dis. 1999:35:647-59.

16. Holt G, Berg C. Sarcoptic mange in red foxes and other carnivores in Norway. Norsk Veterinaertidsskrift. 1990;120:427-32.

17. Lindström E. Pattern of spread and effects of sarcoptic mange among red fox populations in Sweden. In: Bobek B, Perzanowski K, Regelin WL, editors. Global trends in wildlife management: 18th IUGB Congress. Krakow: Swiat Press; 1991. p. 591-5.

18. Gortázar C, Villafuerte R, Blanco JC, Fernández-De-Luco D. Enzootic sarcoptic mange in red foxes in Spain. Eur J Wild Res. 1998;44:251-6.

19. Carricondo-Sanchez D, Odden M, Linnell JDC, Odden J. The range of the mange: spatiotemporal patterns of sarcoptic mange in red foxes (Vulpes vulpes) as revealed by camera trapping. PLoS ONE. 2017; 12:e0176200.

20. Wetzel R, RieckW. Befall mit Räudemilben. In: Wetzel R, Rieck W, editors. Krankheiten des Wildes. Hamburg and Berlin: Verlag Paul Parey; 1962. p. 144-51.

21. Mörner T, Christensson D. Experimental infection of red foxes (Vulpes vulpes) with Sarcoptes scabiei var. vulpes. Vet Parasitol. 1984;15:159-64.

22. Kołodziej-Sobocińska M, Zalewski A, Kowalczyk R. Sarcoptic mange vulnerability in carnivores of the Białowieża Primeval Forest, Poland. Ecol Res. 2014;29:237-44.

23. Lloyd HG. Parasites and diseases. In: Lloyd HG, editor. The red fox. London: Redwood Burn Ltd; 1980. p. 223-51.

24. Currier RW, Walton SF, Currie BJ. Scabies in animals and humans: history, evolutionary perspectives, and modern clinical management. Ann NY Acad Sci. 2011;1230:E50-60

25. Roncalli RA. The history of scabies in veterinary and human medicine from biblical to modern times. Vet Parasitol. 1987;25:193-8.

26. Mégnin P. Acariens. Les parasites articulés chez l'homme et les animaux utiles (maladies qu'ils occasionnent). Paris: Nabu Press; 1895. p. 158-89.

27. Knowles MF. Fighting coyotes with mange inoculation. Breeding Gazette. 1914;66:229-30.

28. Ölt A, Ströse A. Die Räude. In: Ölt A, Ströse A, editors. Die Wildkrankheiten und ihre Bekämpfung. Neudamm: Neumann; 1914. p. 358-98.

29. Jackson HT. Mammals of Wisconsin. Madison: University of Wisconsin Press; 1961

30. Delafond O, Bourguignon $\mathrm{H}$. Traité pratique d'entomologie et de pathologie comparée de la psore. Paris: Imprimerie impériale; 1862.

31. Walz GH. De la gale des moutons, de sa nature, de ses causes et des moyens de la guérir. Paris: Huzard; 1811.

32. Pryor LB. Sarcoptic mange in wild foxes in Pennsylvania. J Mammal. 1956;37:90-3.

33. Storm GL, Andrews RG, Phillips RL, Bishop RA, Sniff DB, Tester JR. Morphology, reproduction, dispersal and mortality of midwestern red fox populations. Wildl Monogr. 1976;49:3-82.

34. Fraser TA, Charleston M, Martin A, Polkinghorne A, Carver S. The emergence of sarcoptic mange in Australian wildlife: an unresolved debate. Parasit Vectors. 2016;9:316.

35. Peltier SK, Brown JD, Ternent M, Niedringhaus KD, Schuler K, Bunting EM, et al. Genetic characterization of Sarcoptes scabiei from black bears (Ursus americanus) and other hosts in the eastern United States. J Parasitol. 2017;103:593-7.

36. Kriechbaum C, Pomroy W, Gedye K. Sarcoptes scabiei on hedgehogs in New Zealand. Parasitol Res. 2018;117:697-703.

37. Niedringhaus KD, Brown JD, Ternent M, Childress W, Gettings JR, Yabsley MJ. The emergence and expansion of sarcoptic mange in American 
black bears (Ursus americanus) in the United States. Vet Parasitol Reg Stud Reports. 2019;17:100303.

38. Bates P. Sarcoptic mange (Sarcoptes scabiei var. vulpes) in a red fox (Vulpes vulpes) population in north-west Surrey. Vet Rec. 2003;152:112-4.

39. Simpson VR. Wild animals as reservoirs of infectious diseases in the UK Vet J. 2002;163:128-46.

40. Schuster R, Wanjek C, Bartnik C, Wittstatt U, Baumann M, Schein E. Liver fluke infection and sarcoptic mange in red foxes in Berlin. Berl Munch Tierarztl Wochenschr. 2001;114:193-6.

41. Ochs H, Müller U, Fischer C. Fuchsräude kehrt in die Schweiz zurück. Jagd Natur. 1998;11:35-6.

42. Haas C, Origgi FC, Akdesir E, Batista Linhares M, Giovannini S, Mavrot F, et al. First detection of sarcoptic mange in free-ranging wild boar (Sus scrofa) in Switzerland. Schweiz Arch Tierheilkd. 2015;157:269-75.

43. Wandeler P. Spatial and temporal population genetics of Swiss red foxes (Vulpes vulpes) following a rabies epizootic. PhD thesis, Cardiff University; 2004

44. Alasaad S, Rossi L, Soriguer RC, Rambozzi L, Soglia D, Perez JM, et al. Sarcoptes mite from collection to DNA extraction: the lost realm of the neglected parasite. Parasitol Res. 2009;104:723-32.

45. Fain A. Etude de la variabilité de Sarcoptes scabiei avec une révision des Sarcoptidae. Acta Zool Path Antverspiensia. 1968;47:1-196.

46. Pewsner M, Origgi FC, Frey J, Ryser-Degiorgis M-P. Assessing fifty years of general health surveillance of roe deer in Switzerland: a retrospective analysis of necropsy reports. PLoS ONE. 2017;12:e0170338.

47. Zanoni RG, Kappeler A, Müller UM, Müller C, Wandeler Al, Breitenmoser U. Rabies-free status of Switzerland following 30 years of rabies in foxes. Schweiz Arch Tierheilkd. 2000;142:423-9.

48. Origgi FC, Plattet P, Sattler U, Robert N, Casaubon J, Mavrot F, et al. Emergence of canine distemper virus strains with modified molecular signature and enhanced neuronal tropism leading to high mortality in wild carnivores. Vet Pathol. 2012:49:913-29.

49. Yon L, Duff JP, Ågren EO, Erdelyi K, Ferroglio E, Godfroid J, et al. Recent changes in infectious diseases in European wildlife. J Wildl Dis. 2019;55:3-43.

50. Breitenmoser U, Müller U, Kappeler A, Zanoni RG. The final stage of rabies in Switzerland. Schweiz Arch Tierheilkd. 2000;142:447-54.

51. Müller U, Kappeler A, Zanoni RG, Breitenmoser U. The development of rabies in Switzerland - landscape determines the spread of a wild life epidemic. Schweiz Arch Tierheilkd. 2000;142:431-8.

52. Zimmermann F. Monitoring von grossen Beutegreifern. In: Heurich M, editor. Wolf, Luchs und Bär in der Kulturlandschaft. Stuttgart: Ulmer; 2019. p. 165-200.

53. Rovero F, Zimmermann F. Camera trapping for wild life research. Data in the wild. Exeter: Pelagic Publishing; 2016.

54. Hallgren KA. Computing inter-rater reliability for observational data: an overview and tutorial. Tutor Quant Methods Psychol. 2012;8:23-34.

55. Wandeler A. Vulpes vulpes (L., 1758). In: Hausser J, editor. Säugetiere der Schweiz - Verbreitung, Biologie, Ökologie. Basel: Birkhäuser Verlag; 1995. p. 407-10.

56. Müller UM, Gloor S, Breitenmoser U. Wildlife vaccination rabies in difficult and emergency situations and its potential impact on the environment. Cost Action Nr. FAIR CT 97-3515, BBW/OFES-NB. 97.0586; Bern; 2001.

57. Köchlin RJ. Über die in unseren Zeiten unter den Füchsen herrschende Krankheit und die Natur und Ursachen der Wuthkrankheit überhaupt. Zurich: Orell, Füssli und Compagnie; 1835.

58. Di Vigo G. Prattica universale in cirurgia dell'eccellente M. Giovanni di Vigo: et il dotto compendio di Mariano suo discepolo; opere non meno utili, che necessarie a gli studiosi di tal'arte. Venezia: Domenico \& Cornelio de Nicolini; 1560

59. Fodéré F-E. Traité de médecine légale et d'hygiène publique ou police de santé, adapté aux codes de l'Empire français et aux connaissances actuelles. Paris: Mame; 1813.

60. Anonymus. Anmerkung über die Witterung des Novembers und deren Wirkung. Wittenbergisches Wochenblatt. 1772. p. 389-92.

61. Fitzinger $L J$. Wissenschaftlich-populäre Naturgeschichte der Säugetiere in ihren sämmtlichen Hauptformen. Nebst einer Einleitung in die Naturgeschichte überhaupt und in die Lehre von den Thieren insbesondere.
Wien: Druck und Verlag der Kais. Kön. Hof- und Staatdruckerei; 1855. p. 152-263.

62. Müller FT, Freuling CM. Rabies control in Europe: an overview of past, current and future strategies. Rev Sci Tech. 2018;37:409-19.

63. Steck F, Wandeler A. The epidemiology of fox rabies in Europe. Epidemiol Rev. 1980;2:71-96.

64. Wandeler Al, Kappeler A, Capt S. Sarcoptic mange in foxes in Switzerland. Rev Ecol. 1985;40:240.

65. Bouvier G. Quelques maladies du gibier transmissibles à l'homme et aux animaux domestiques: danger pour l'homme et mesures de précaution. Schweiz Z Forstwes. 1970;121:697-703.

66. Gesellschaft N. Die Zoologische Sammlung. An die Zürcherische Jugend. 1843;65:1-14.

67. Steck F, Addy P, Schipper E, Wandeler A. Der bisherige Verlauf des Tollwutseuchenzuges in der Schweiz. Schweiz Arch Tierheilkd. 1968:110:597-616.

68. Bouvier G, Bürgisser H, Schneider PA. Observations sur les maladies du gibier, des oiseaux et des poissons faites en 1953 et 1954. Schweiz Arch Tierheilkd. 1955;97:318-25.

69. Walton Z, Samelius G, Odden M, Willebrand T. Variation in home range size of red foxes Vulpes vulpes along a gradient of productivity and human landscape alteration. PLoS ONE. 2017;12:e0175291.

70. Zecchin B, De Nardi M, Nouvellet P, Vernesi C, Babbucci M, Crestanello B, et al. Genetic and spatial characterization of the red fox (Vulpes vulpes) population in the area stretching between the eastern and Dinaric Alps and its relationship with rabies and canine distemper dynamics. PLoS ONE. 2019;14:e0213515.

71. Mullins J, McDevitt AD, Kowalczyk R, Ruczyńska I, Górny M, Wójcik $J M$. The influence of habitat structure on genetic differentiation in red fox populations in north-eastern Poland. Acta Theriol (Warsz). 2014:59:367-76.

72. Murray KA, Olivero J, Roche B, Tiedt S, Guégan J-F. Pathogeography: leveraging the biogeography of human infectious diseases for global health management. Ecography. 2018;41:1411-27.

73. Kozakiewicz CP, Burridge CP, Funk WC, VandeWoude S, Craft ME, Crooks $\mathrm{KR}$, et al. Pathogens in space: advancing understanding of pathogen dynamics and disease ecology through landscape genetics. Evol Appl. 2018:11:1763-78.

74. Herrera J, Nunn CL. Behavioural ecology and infectious disease: implications for conservation of biodiversity. Philos Trans R Soc Lond B Biol Sci. 2019;374:20180054.

75. Kappeler A, Wandeler Al. The development of strategies for the field application of oral immunization of foxes against rabies. Schweiz Arch Tierheilkd. 2000;142:439-46.

76. Chautan M, Pontier D, Artois M. Role of rabies in recent demographic changes in the red fox (Vulpes vulpes) populations in Europe. Mammalia. 2000;4:391-410.

77. O'Brien SJ, Evermann JF. Interactive influence of infectious disease and genetic diversity in natural populations. Trends Ecol Evol. 1988;3:254-9.

78. DeCandia AL, Brzeski KE, Heppenheimer E, Caro CV, Camenisch G, Wandeler $\mathrm{P}$, et al. Urban colonization through multiple genetic lenses: the city-fox phenomenon revisited. Ecol Evol. 2019;9:2046-60.

79. Marshall HD, Langille BL, Hann CA, Whitney HG. Patterns of MHC-DRB1 polymorphism in a post-glacial island canid, the Newfoundland red fox (Vulpes vulpes deletrix), suggest balancing selection at species and population timescales. Immunogenetics. 2016;68:381-9.

80. Ostfeld RS, Keesing F. Effects of host diversity on infectious disease. Annu Rev Ecol Evol Syst. 2012;43:157-82.

81. Ploshnitsa Al, Goltsman ME, Macdonald DW, Kennedy LJ, Sommer S. Impact of historical founder effects and a recent bottleneck on MHC variability in Commander arctic foxes (Vulpes lagopus). Ecol Evol. 2012:2:165-80

82. Meia J-S, Weber J-M. Home ranges and movements of red foxes in central Europe: stability despite environmental changes. Can J Zool. 1995;73:1960-6.

83. Trewhella WJ, Harris S, MCAllister FE. Dispersal distance, home-range size and population density in the red fox (Vulpes vulpes): a quantitative analysis. J Appl Ecol. 1988;25:423-34.

84. Lindström E, Mörner T. The spreading of sarcoptic mange among Swedish red foxes (Vulpes vulpes) in relation to fox population dynamics. Rev Ecol. 1985:40:211-6. 
85. European Environment Agency, Federal Office for the Environment. Landscape fragmentation in Europe. Luxembourg: Publications Office of the European Union; 2011. https://www.eea.europa.eu/publications/ landscape-fragmentation-in-europe.

86. Gloor S, Bontadina F, Hegglin D, Deplazes P, Breitenmoser U. The rise of urban fox population in Switzerland. Mamm Biol. 2001;66:155-64.

87. Brönnimann S, Appenzeller C, Croci-Maspoli M, Fuhrer J, Grosjean M Hohmann R, et al. Climate change in Switzerland: a review of physical, institutional, and political aspects. WIRE's Clim Change. 2014:5:461-8.

88. Mulatti P, Bonfanti L, Patregnani T, Lorenzetto M, Ferre N, Gagliazzo L, et al. 2008-2011 sylvatic rabies epidemic in Italy: challenges and experiences. Pathog Glob Health. 2013;107:346-53.

89. Davidson RK, Bornstein S, Handeland K. Long-term study of Sarcoptes scabiei infection in Norwegian red foxes (Vulpes vulpes) indicating host/ parasite adaptation. Vet Parasitol. 2008;156:277-83.

90. Pence DB, Windberg LA. Impact of a sarcoptic mange epizootic on a coyote population. J Wildl Manage. 1994;58:624-33.

91. Lindström ER, Andrén H, Angelstam $P$, Cederlund G, Hörnfeldt B, Jäderberg $L$, et al. Disease reveals the predator: sarcoptic mange, red fox predation and prey populations. Ecology. 1994;75:1042-9.

92. Borgsteede FH. The effect of parasites on wildlife. Vet Q. 1996;18(Suppl. 3):138-40.

93. Nouvellet P, Donnelly CA, De Nardi M, Rhodes CJ, De Benedictis P, Citterio $C$, et al. Rabies and canine distemper virus epidemics in the red fox population of northern Italy (2006-2010). PLOS ONE. 2013;8:e61588.

94. Gordon CH, Banyard AC, Hussein A, Laurenson MK, Malcolm JR, Marino $J$, et al. Canine distemper in endangered Ethiopian wolves. Emerg Infect Dis. 2015;21:824-32.

95. Almberg ES, Cross PC, Dobson AP, Smith DW, Hudson PJ. Parasite invasion following host reintroduction: a case study of Yellowstone's wolves. Philos Trans R Soc Lond B Biol Sci. 2012;367:2840-51.

96. Altizer S, Harvell D, Friedle E. Rapid evolutionary dynamics and disease threats to biodiversity. Trends Ecol Evol. 2003;18:589-96

97. Jolles AE, Ezenwa VO. Ungulates as model systems for the study of disease process in natural populations. J Mammal. 2015;96:4-15.

98. Macphee RD, Greenwood AD. Infectious disease, endangerment, and extinction. Int J Evol Biol. 2013;2013:571939.

99. Rohani P, Green CJ, Mantilla-Beniers NB, Grenfell BT. Ecological interference between fatal diseases. Nature. 2003;422:885-8.

100. Jolles AE, Etienne RS, Olff H. Independent and competing disease risks: implications for host populations in variable environments. Am Nat. 2006;167:745-57.
101. Oleaga A, Vicente J, Ferroglio E, Pegoraro de Macedo MR, Casais R, del Cerro A, et al. Concomitance and interactions of pathogens in the Iberian wolf (Canis lupus). Res Vet Sci. 2015;101:22-7.

102. Laurimaa L, Moks E, Soe E, Valdmann H, Saarma U. Echinococcus multilocularis and other zoonotic parasites in red foxes in Estonia. Parasitology. 2016;143:1450-8.

103. Cliquet F, Robardet E, Must K, Laine M, Peik K, Picard-Meyer E, et al. Eliminating rabies in Estonia. PLoS Negl Trop Dis. 2012;6:e1535.

104. Plumer L, Davison J, Saarma U. Rapid urbanization of red foxes in Estonia: distribution, behaviour, attacks on domestic animals, and health-risks related to zoonotic diseases. PLoS ONE. 2014;9:e115124.

105. Ryser-Degiorgis M-P. Wildlife health investigations: needs, challenges and recommendations. BMC Vet Res. 2013;9:223.

106. Portier J, Ryser-Degiorgis M-P, Hutchings MR, Monchâtre-Leroy E, Richomme C, Larrat S, et al. Multi-host disease management: the why and the how to include wildlife. BMC Vet Res. 2019;15:295.

107. Mahood Q, Van Eerd D, Irvin E. Searching for grey literature for systematic reviews: challenges and benefits. Res Synth Methods. 2014;5:221-34.

108. Sadlier LMJ, Webbon CC, Baker PJ, Harris S. Methods of monitoring red foxes Vulpes vulpes and badgers Meles meles: are field signs the answer? Mamm Rev. 2004;34:75-98.

109. Beltrán JF, Delibes M, Rau J. Methods of censuring red fox (Vulpes vulpes) populations. Hystrix. 1991;3:199-214.

110. Oleaga A, Casais R, Balseiro A, Espí A, Llaneza L, Hartasánchez A, et al. New techniques for an old disease: sarcoptic mange in the lberian wolf. Vet Parasitol. 2011;181:255-66.

111. Brewster K, Henke SE, Hilton C, Ortega SA Jr. Use of remote cameras to monitor the potential prevalence of sarcoptic mange in southern Texas, USA. J Wildl Dis. 2017;53:377-81.

112. Hofmeester TR, Cromsigt JPGM, Odden J, Andrén H, Kindberg J, Linnell JDC. Framing pictures: a conceptual framework to identify and correct for biases in detection probability of camera traps enabling multispecies comparison. Ecol Evol. 2019;9:2320-36.

113. Sarmento P, Cruz J, Eira C, Fonseca C. Evaluation of camera trapping for estimating red fox abundance. J Wildl Manage. 2009;73:1207-12.

\section{Publisher's Note}

Springer Nature remains neutral with regard to jurisdictional claims in published maps and institutional affiliations.
Ready to submit your research? Choose BMC and benefit from:

- fast, convenient online submission

- thorough peer review by experienced researchers in your field

- rapid publication on acceptance

- support for research data, including large and complex data types

- gold Open Access which fosters wider collaboration and increased citations

- maximum visibility for your research: over $100 \mathrm{M}$ website views per year

At BMC, research is always in progress.

Learn more biomedcentral.com/submissions 